\title{
Comperative Evaluation of Vitek 2 and Etest Methods with the Referance Broth Microdilution for Antimicrobial Susceptibility Testing of Colistin Among Multi-Drug Resistant Gram-Negative Bacteria
}

\section{Çoklu İlaca Dirençli Gram-Negatif Bakterilerde Kolistin in Vitro Duyarııı̃ının Belirlenmesinde Referans Sıvı Mikrodilüsyon Metodu ile Vitek 2 ve Etest Yöntemlerinin Karșılaștırmalı Olarak Deg̃erlendirilmesi}

Selin UG̃RAKLI'(ID), Metin DOG̃AN²(ID)

\footnotetext{
${ }^{1}$ Division of Medical Microbiology, Konya Public Health Laboratory, Konya, Turkey

${ }^{2}$ Department of Medical Microbiology, Necmettin Erbakan University Meram Faculty of Medicine, Konya, Turkey
}

Cite this article as: Uğraklı S, Doğan M. Comperative evaluation of Vitek 2 and etest methods with the referance broth microdilution for antimicrobial susceptibility testing of colistin among multi-drug resistant gram-negative bacteria. FLORA 2021;26(3):518-27.

\begin{abstract}
Introduction: Despite the increased need for colistin, especially in serious infections caused by carbapenem resistant gram-negative bacteria, problems and challenges regarding colistin susceptibility testing remain. The aim of this study was to evaluate the performance of Vitek 2, one of the commonly used automated systems, and Etest for colistin susceptibility testing compared with reference broth microdilution method (BMD).

Materials and Methods: This study included 657 multi-drug resistance (MDR) Gram negative bacteria obtained from clinical samples; Negative control, Escherichia coli ATCC 25922 and Positive control, Escherichia coli NCTC 13846. The collected MDR isolates were performed colistin BMD according to ISO standard 20776-1, prospectively. Categorical agreement (CA), Very Major Error (VME), and Major Error (ME) rate were calculated. Acceptable performance was evaluated as; $C A \geq 90 \%$; VME $<1.5 \%$ and $M E<3 \%$.

Results: Colistin resistance rates were detected by Vitek 2, Etest and BMD; 40.3\%, 48.7\%, 53.9\%, respectively. CA rates were as follows: Vitek $292.4 \%$ and Etest 71.9\%. While the compatibility of Vitek 2 and BMD was observed (kappa value $=0.85$ ) to be 'excellent agreement'; the agreement of Etest and BMD was found to be 'moderate' (kappa value $=0.45$ ). Although CA varied from $85.7 \%$ to $100 \%$ for Vitek 2, it ranged $63.6 \%$ to $80 \%$ for Etest depending on bacterial species. Alarming high rates of VME were determined for Vitek 2 (14.5\%) and Etest (36.5\%). While MEs were 1.7\% by Vitek 2; there was no false resistant isolate with Etest.

Conclusion: It may be recommended for laboratories not to rely on Vitek 2 and Etest colistin susceptibility results. Additionally, colistin resistant isolates will be underestimated by reducing colistin susceptibility studies to a specific minimum inhibitory concentration (MIC). In this regard, our suggestion is that laboratories would improve their infrastructure and staff skills to apply BMD routinely.
\end{abstract}

Key Words: Antimicrobial resistance; Colistin; Broth microdilution

Received/Geliș Tarihi: 11/03/2021 - Accepted/Kabul Ediliș Tarihi: 12/05/2021 


\title{
Öz
}

\section{Çoklu Iilaca Dirençli Gram-Negatif Bakterilerde Kolistin in Vitro Duyarlılıg̃ının Belirlenmesinde Referans Sıvı Mikrodilüsyon Metodu ile Vitek 2 ve Etest Yöntemlerinin Karșılaștırmalı Olarak Deg̃erlendirilmesi}

\author{
Selin UG̃RAKLI', Metin DOG̃AN²
}

\author{
${ }^{1}$ Konya Halk Sag̃lığı Laboratuvarı, Tıbbi Mikrobiyoloji Birimi, Konya, Türkiye \\ ${ }^{2}$ Necmettin Erbakan Üniversitesi Meram Tıp Fakültesi, Tıbbi Mikrobiyoloji Anabilim Dalı, Konya, Türkiye
}

\begin{abstract}
Giriş: Kolistin ihtiyacının artmasına rağmen, özellikle karbapenem dirençli gram-negatif bakterilerin neden olduğu ciddi infeksiyonlarda; kolistin duyarlıık testi ile ilgili sorunlar ve zorluklar devam etmektedir. Bu çalışmanın amacı kolistin duyarlıı̆ııın belirlenmesinde yaygın olarak kullanılan otomatize sistemlerden Vitek 2'nin ve Etest yönteminin referans SIVı mikrodilüsyon metodu (BMD) ile karşılaştırılmalı olarak değerlendirilmesidir.
\end{abstract}

Materyal ve Metod: Bu çalışmaya, klinik örneklerden izole edilen çoklu ilaca dirençli (MDR) 657 gram-negatif bakteri ve Negatif kontrol, Escherichia coli ATCC 25922; Pozitif kontrol, Escherichia coli NCTC 13846 suşları dahil edildi. Stoktaki MDR izolatlar ISO standart 29776-1'e uygun olarak kolistin sıvı mikrodilüsyon metodu ile prospektif olarak çalışıldı. Kategorik uyum (KU), Çok Büyük Hata (ÇBH), Büyük Hata (BH) oranları hesaplandı. $K U \geq \% 90 ; C ̧ B H<\% 1.5$ ve $B H<\% 3$ kabul edilebilir performans kriterleri olarak alındı.

Bulgular: Kolistin direnç oranları Vitek 2, Etest ve BMD yöntemleriyle sırasıyla \%40.3, \%48.7, \%53.9 olarak tespit edildi. KU oranları Vitek $2 \% 92.4$; Etest \%71.9 olarak bulundu. Vitek 2-BMD uyumu analiz neticesinde mükemmel (kappa değeri: 0.85) iken; Etest-BMD orta derecede uyumlu bulundu (kappa değeri: 0.45). Kategorik uyum Vitek 2 için \%85.7 ile \%100 arasında değişirken; Etest de bakteri türlerine göre kategorik uyum \%63.6 ile \%80 aralı̆ında tespit edildi. Endişe veren yüksek çok büyük hata oranları Vitek 2 için \%14.5 ve Etest için \%36.5 olarak hesaplandı. Vitek 2 için belirlenen büyük hata oranı \%1.7 iken; Etest ile hiçbir izolat yanlış dirençli olarak saptanmadı.

Sonuç: Laboratuvarlara Vitek 2 ve Etest kolistin duyarlılık testi sonuçlarına güvenmemeleri tavsiye edilebilir. Ek olarak, kolistin duyarlılık çalışmalarını spesifik bir minimum inhibitör konsantrasyon (MiK) değerine göre sınırlamak kolistin dirençli izolatların gözden kaçmasına sebep olabilir. Bu kapsamda, sıvı mikrodilüsyon yönteminin rutin olarak kullanılması amacıyla laboratuvarların altyapı ve becerilerinin geliştirilmesini önermekteyiz.

Anahtar Kelimeler: Antimikrobiyal direnç; Kolistin; Sıvı Mikrodilüsyon

\section{INTRODUCTION}

Infections caused by multidrug-resistant Gram-negative bacteria (MDRGN) remain a significant challenge associated with high morbidity and mortality worldwide $e^{[1]}$. The misuse and extensive use of antibiotics have led to widespread resistance to carbapenems, one of the current broad spectrum antibiotics ${ }^{[2]}$. Due to the limited efficient agent against infections with carbapenem-resistant Enterobacterales (CRE), an older class of antibiotics such as polymyxins have reemerged $^{[3]}$.

Colistin (Polymyxin E) was synthesized in the 1940 s and used by the $1970 s^{[4]}$. The use of colistin is abandoned due to its serious nephro- toxic and neurotoxic effects. Nevertheless, it is now increasingly being used as a 'last-line' therapeutic option in serious infections caused by MDRGN, particularly carbapenem-resistant (CR) Gram-negative bacteria. Currently, with the increasing use of colistin, a need for reliable and rapid antibiotic susceptibility testing (AST) have became crucial ${ }^{[3]}$. Because of the its large structure, colistin cannot be sufficiently diffused to agar medium. Therefore, false sensitive results may occur in agar-based antibiotic susceptibility tests (disk diffusion test, gradient test e.g. (5-7]. $^{[5}$. Concerning the discrepancy in colistin sensitivity test results, the "European Committee on Antimicrobial Susceptibility Testing" (EUCAST) stated that the minimum inhibitory concentration (MIC) 
of the colistin detected in gradient tests underestimate, and the disk diffusion method shall not be used for AST. Both the EUCAST and the "Clinical and Laboratory Standards Institute" (CLSI) joint working group recommended the broth microdilution method (BMD) as the only valid susceptibility testing method for colistin ${ }^{[8,9]}$.

The aim of this prospective study was to investigate the performance of Vitek 2 automated system and Etest compared with reference Broth Microdilution Method for colistin susceptibility test of MDRGN isolates.

\section{MATERIALS and METHODS}

\section{Study Design}

A total of 657 non-duplicate clinical strains of gram-negative bacteria isolated from various samples sent to Microbiology Laboratory of Necmettin Erbakan University Meram Medical Faculty between January 2019-June 2020 were included. The study was approved by the local ethics committee.

\section{Antimicrobial Susceptibility Testing}

The identification and antibiotic susceptibility tests were performed by Vitek 2 (bioMérieux, Marcy l'Etoile, France) for each strain in accordance with EUCAST guidelines ${ }^{[10]}$. Strains were classified as multi-drug resistance (MDR) if they were resistant to at the least three classes of antimicrobial agents ${ }^{[1]}$. Of the 203 isolates were performed Etest (bioMйrieux, Marcy l'Etoile, France) simultaneously. Both Vitek 2 and Etest were interpreted according to the manufacturer's recommendations. The possible range of $\mathrm{MIC}$ readings for Vitek was $<=0.5 \mathrm{mg} / \mathrm{L}$ to $>=16$ $\mathrm{mg} / \mathrm{L}$, it was 0.016 to $256 \mathrm{mg} / \mathrm{L}$ for Etest.

\section{In-House Broth Microdilution (BMD)}

The active ingredient colistin sulphate powder was acquired from Sigma-Aldrich (St Louis, $\mathrm{MO}, \mathrm{USA})$. It was dissolved in accordance with the recommendations of the manufacturer and stock solutions were obtained in $128 \mathrm{mg} / \mathrm{L}$ concentration. All of the isolates were cultivated from stock cultures for colistin broth microdilution testing. BMD was performed according to International Organization for Standardization (ISO) 20776-1 ${ }^{[11]}$ in 96-well untreated polyst- yrene trays using cation-adjusted BBL Mueller Hinton II broth (Becton Dickinson and Company Sparks, MD 21152, USA). Serial dilutions (0.32$32 \mathrm{mg} / \mathrm{L})$ were prepared in Mueller-Hinton broth on microdilution plates from the stock solution. The last wells served as growth control. After preparing a suspension with $0.5 \mathrm{McFarland}$ standard turbidity from all collected isolates, the final bacteria concentration was added to microdilution plates at $5 \times 10^{5} \mathrm{cfu} / \mathrm{ml}$ and the microplates were incubated at $36^{\circ} \mathrm{C}$ for $18-24$ hours. The lowest concentration of colistin without growth was determined as the MIC value. Escherichia coli ATCC 25922 (target MIC 0.5 to $1 \mathrm{mg} / \mathrm{L}$, range 0.25 to 2 ) and $\mathrm{mcr}-1$ positive $E$. coli NCTC 13846 (target MIC $4 \mathrm{mg} / \mathrm{L}$, range 2 to 8) standard bacteria were used for colistin sensitive and colistin resistant controls, respectively.

\section{Analysis of Data}

The results were evaluated according to the clinical breakpoints specified in the EUCAST standards $(\leq 2 \mathrm{mg} / \mathrm{L}$ colistin sensitive and $>2$ $\mathrm{mg} / \mathrm{L}$ colistin resistant) ${ }^{[10]}$. BMD was accepted as the reference method for determination of $\mathrm{co}^{-}$ listin sensitivity. MIC50 and MIC90 values were calculated based on BMD results as the MICs at which $50 \%$ and $90 \%$ of the isolates were inhibited, respectively. Very major errors (VME) were determined as 'susceptible' according to Vitek 2 systems or Etest and 'resistant' according to BMD; major errors (ME) were defined as 'resistant' according to Vitek 2 systems or Etest and 'susceptible' according to BMD. Categorical agreement (CA) was calculated by the rate of isolates with the same susceptibility category using the total number of isolates performed as the denominator. Acceptable performance according to the criteria determined by CLSI; CA $\geq 90 \%$; VME $<1.5 \%$ and $\mathrm{ME}<3 \%[12,13]$. The agreement in categorical outcomes was evaluated by the Cohen's kappa statistics. Analyzes were performed with Jamovi 1.2.22 program.

\section{RESULTS}

A total of 657 multi-drug resistant gramnegative bacilli, most of which were isolated from intensive care units ( $n=459,69.9 \%)$, included in the study were as follows: Klebsiella pneumoniae 
$\mathrm{n}=538$; Acinetobacter baumannii complex $\mathrm{n}=90$; Pseudomonas aeruginosa $\mathrm{n}=14$; Escherichia coli $\mathrm{n}=11$; Enterobacter cloacae complex $\mathrm{n}=4$. The sensitivity of colistin for the samples examined is summarized in Table 1 , blood $(\mathrm{n}=303,46.1 \%)$ and bronchoalveolar lavage $(\mathrm{n}=190,28.9 \%)$ samples were constituted the vast majority of the specimens. The distribution of isolates according to colistin MICs values determined by reference broth microdilution method is given in Table 2 .

Meropenem resistance was detected in 555 $(84.5 \%)$ of 657 isolates. Of these 555 isolates with carbapenem resistance, 291 (52.43\%) were also found to be resistant to colistin. However, resistance to colistin was detected in only 12 $(11.8 \%)$ of 102 isolates that were susceptible to meropenem.
The categorical agreement (CA) varied from $85.7 \%$ to $100 \%$ for the Vitek 2 and from $63.6 \%$ to $80 \%$ for the Etest (Table 3) CA rate was $92.4 \%$ in the colistin susceptibility with the Vitek 2 for all isolates. Despite acceptable CA rate was determined via Vitek 2 generally, significant differences of agreement were observed according to the bacterial specie evaluated (Table 3). In this study, when compared with Enterobacterales; the categorical agreement of Vitek 2 was lower for non-fermentative bacilli. In addition, $14.5 \%$ of very major errors (VME) and $1.7 \%$ of major errors (ME) were determined by Vitek 2 (Table 3 ). Although the categorical agreement and major errors were within acceptable limits $(>90 \%$; $<3 \%$; respectively), high percentage of VME (44 false susceptible, 14.5\%) was observed, which was over the criterion of $\leq 1.5 \%$. The highest number

Table 1. Colistin sensitivity rates according to the source of sampling

\begin{tabular}{|c|c|c|c|}
\hline Sampling Source & Colistin Resistant (n) & Colistin Sensitive (n) & Total (n) \\
\hline Cerebrospinal fluid & 4 & 0 & 4 \\
\hline Pus & 0 & 3 & 3 \\
\hline Bronchoalveolar lavage & 115 & 75 & 190 \\
\hline Sputum & 6 & 3 & 9 \\
\hline Drainage & 3 & 17 & 20 \\
\hline Urine & 28 & 33 & 61 \\
\hline Blood & 118 & 185 & 303 \\
\hline Catheter & 6 & 5 & 11 \\
\hline Pleura fluid & 1 & 1 & 2 \\
\hline Wound & 22 & 32 & 54 \\
\hline Total & 303 & 354 & 657 \\
\hline
\end{tabular}

Table 2. Distribution of isolates according to colistin MICs values determined by reference broth microdilution method

\begin{tabular}{|c|c|c|c|c|c|c|c|c|c|c|}
\hline \multirow[t]{2}{*}{ Type of Bacteria } & \multicolumn{10}{|c|}{ Distribution of Isolates by MIC Values (mg/L) } \\
\hline & 0.064 & 0.125 & 0.25 & 0.5 & 1 & 2 & 4 & 8 & 16 & 32 \\
\hline K. pneumoniae $(\mathrm{n}=538)$ & 5 & 51 & 94 & 76 & 22 & 16 & 15 & 36 & 104 & 119 \\
\hline A. baumannii $(\mathrm{n}=90)$ & - & 8 & 94 & 17 & 12 & 2 & - & 1 & 8 & 17 \\
\hline P. aeruginosa $(n=14)$ & - & - & 4 & 2 & 2 & 3 & - & - & 2 & 1 \\
\hline E. $\operatorname{coli}(\mathrm{n}=11)$ & - & 4 & 6 & 1 & - & - & - & - & - & - \\
\hline E. cloacoae complex $(n=4)$ & - & - & 2 & 2 & - & - & - & - & - & - \\
\hline Total & 5 & 63 & 131 & 98 & 36 & 21 & 15 & 37 & 114 & 137 \\
\hline
\end{tabular}




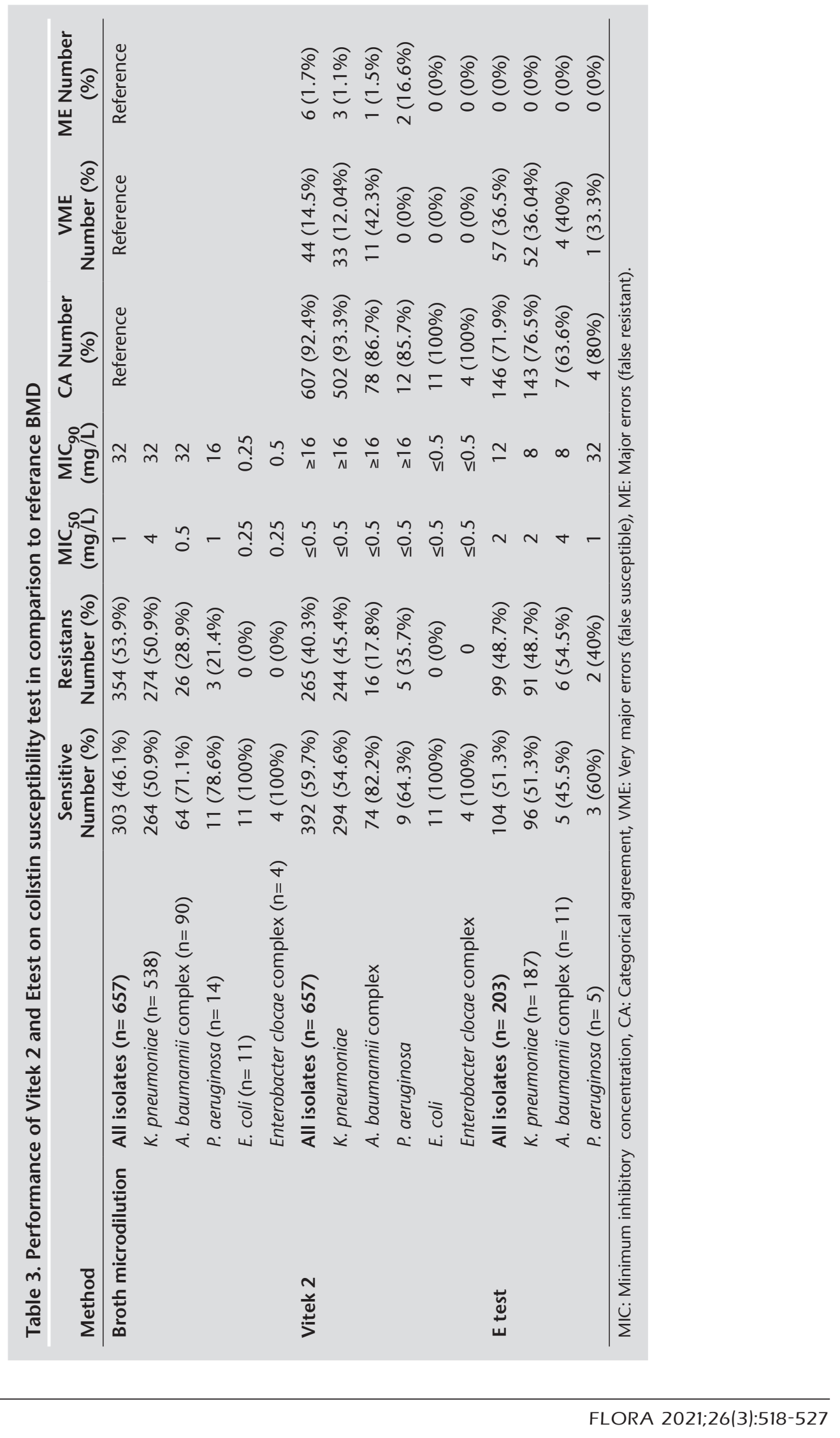


Table 4. Colistin MIC (mg/L) distribution by method

\begin{tabular}{lccccccccccc} 
& \multicolumn{10}{c}{ No. of isolates with MIC $(\mathrm{mg} / \mathrm{L})(\mathrm{n}=\mathbf{6 5 7})$ via BMD } \\
\hline & & $\mathbf{0 . 0 6 4}$ & $\mathbf{0 . 1 2 5}$ & $\mathbf{0 . 2 5}$ & $\mathbf{0 . 5}$ & $\mathbf{1}$ & $\mathbf{2}$ & $\mathbf{4}$ & $\mathbf{8}$ & $\mathbf{1 6}$ & 32 \\
\hline $\begin{array}{l}\text { No. of isolates with MIC } \\
\text { (mg/L) via VITEK 2 }\end{array}$ & $<=0,5$ & 5 & 63 & 128 & 97 & 34 & 12 & 6 & 2 & 11 & 16 \\
$(\mathrm{n}=$ 657) & $\mathbf{1}$ & - & - & 1 & 1 & - & 1 & 2 & - & - & 1 \\
& 2 & - & - & - & - & - & 6 & - & 4 & - & 2 \\
& 4 & - & - & 1 & - & - & - & 1 & 6 & 11 & - \\
& $\mathbf{8}$ & - & - & - & - & - & 1 & 0 & 9 & 8 & 4 \\
& $>=16$ & - & - & 1 & - & 2 & 1 & 6 & 16 & 84 & 114 \\
& Total & $\mathbf{5}$ & $\mathbf{6 3}$ & $\mathbf{1 3 1}$ & $\mathbf{9 8}$ & $\mathbf{3 6}$ & $\mathbf{2 1}$ & $\mathbf{1 5}$ & $\mathbf{3 7}$ & $\mathbf{1 1 4}$ & 137 \\
\hline
\end{tabular}

MIC: Minimum inhibitoryconcentration. The dashed line indicates the EUCAST breakpoint for susceptibility ( $\leq 2 \mathrm{mg} / \mathrm{L})$. Very major error are represented in bold.

Table 5. Distribution of colistin minimum inhibitory concentration by broth microdilution and E-test for the tested isolates

No. of isolates with MIC $(\mathrm{mg} / \mathrm{L})$ via reference BMD $(\mathrm{n}=203)$

\begin{tabular}{|c|c|c|c|c|c|c|c|c|c|c|c|}
\hline & & 0.064 & 0.125 & 0.25 & 0.5 & 1 & 2 & 4 & 8 & 16 & 32 \\
\hline \multirow{11}{*}{$\begin{array}{l}\text { No. of isolates with MIC } \\
(\mathrm{mg} / \mathrm{L}) \text { via Etest }(\mathrm{n}=203)\end{array}$} & 0.125 & 1 & 3 & 1 & - & 1 & - & - & - & - & - \\
\hline & 0.5 & - & 1 & 2 & 1 & - & - & - & - & 5 & 2 \\
\hline & 0.75 & - & 1 & 3 & 1 & 1 & - & - & 1 & 1 & - \\
\hline & 1 & 1 & 2 & 3 & 1 & 3 & 1 & 2 & - & 4 & 5 \\
\hline & 1.5 & 1 & 2 & 3 & 6 & - & 2 & - & 2 & 3 & 10 \\
\hline & 2 & - & - & 1 & 1 & - & 4 & 1 & - & 8 & 13 \\
\hline & 4 & - & - & - & - & - & - & 2 & 8 & 23 & 17 \\
\hline & 8 & - & - & - & - & - & - & - & 2 & 8 & 17 \\
\hline & 12 & - & - & - & - & - & - & - & 1 & 3 & 3 \\
\hline & 16 & - & - & - & - & - & - & - & - & - & 4 \\
\hline & 32 & - & - & - & - & - & - & - & 1 & 2 & 8 \\
\hline Total & & 3 & 9 & 13 & 10 & 5 & 7 & 5 & 15 & 57 & 79 \\
\hline
\end{tabular}

MIC: Minimum inhibitory concentration. The dashed line indicates the EUCAST breakpoint for susceptibility $(\leq 2 \mathrm{mg} / \mathrm{L})$. Very major error are represented in bold.

of VME in relation to the species were observed for isolates of $A$. baumannii complex in both the Vitek 2 (42.3\%) and Etest (40\%). It is important to emphasize that the majority of VME detected by Etest was at the borderline MIC $1.5-2 \mathrm{mg} / \mathrm{L}$ while the MIC majority of VME observed with Vitek 2 was $<0.5 \mathrm{mg} / \mathrm{L}$ for $K$. pneumoniae isolates (Table 3). Discrepancies were determined in colisin MIC values reported via the Vitek 2 systems versus the reference in house broth microdilution (Table 4).
The distribution of colistin MIC determined by Etest versus the reference BMD method are given in Table 5. The categorical agreement rate for colistin Etest was observed $71.9 \%$ as quite poor. According to BMD, Etest exhibited lower performance than Vitek 2 for all isolates. Although the highest categorical agreement among isolates was detected in $P$. aeruginosa, this $\mathrm{CA}$ rate is below the acceptable limit of $>90 \%$. Besides, high percentages of VME (57 false susceptible, 36.5\%) was detected by Etest for tested isolates. 
Although the rate of VME detected for $P$. aeruginosa was high by Etest, only one isolate was given as 'false susceptible'. Therefore; the number of isolates for $P$. aeruginosa tested with the Etest is limited for generalization. Additionally, according to the BMD; no major error (ME) was detected by the Etest. However, Vitek 2 showed marginally higher $\mathrm{ME}$ rate (1.7\%).

Inter-method agreement was also evaluated using Cohen's kappa statistics. While the compatibility of Vitek 2 and BMD was observed (kappa value $=0.85$ ) to be 'excellent agreement'; The agreement of Etest and BMD was found to be 'moderate' (kappa value= 0.45).

\section{DISCUSSION}

The emerging resistance to colistin has become a new threat for global public health. The determination of colistin in vitro antibiotic susceptibility testing (AST) is obviously essential for patient management and the monitoring of colistin resistance ${ }^{[13,14]}$. However, there is no reliable, reproducible and practical technique. In the report published by EUCAST, it is stated that disc diffusion method cannot be used in determining the sensitivity of colistin; it does not differentiate sensitive-resistant isolates. Another drawback induced by EUCAST; even when quality control results are within range; available gradient stripes underestimate colistin MIC values, undervalued colistin resistance and so, the use of these tests should be avoided. Additionally, the recommended broth microdilution method is ideal; it is impractical, laborious and time consuming method ${ }^{[9,13-15]}$. Furthermore, the performance of commercial automated systems in detecting colistin sensitivity has not also been evaluated by EUCAST until now ${ }^{[9,15]}$. However, many studies in the literature have disclosed the frequent occurrence of VMEs in automated systems colistin susceptibility results $[6,9,16]$.

In the present study, we compared the performance of Vitek 2, which are frequently used commercial semi-automated systems and gradient test (Etest) with in house prepared broth microdilution method.

In this study, colistin resistance rate was observed as $53.9 \%$ for all isolates via BMD method. These high colistin resistance rates are similar to the recent studies conducted in Turkey ${ }^{[5]}$. In the studies using the BMD method, colistin resistance rates have been reported as $39.5 \%$ by Kocak et al. ${ }^{[17]}$ and $76.2 \%$ by Yildiz et al. ${ }^{[18]}$ from Turkey. Colistin resistance was found to be $92.1 \%(35 / 38)$ by Kansak et al. ${ }^{[19]}$.

In this study, among Enterobacterales family members, $K$. pneumoniae was the most common genus associated with colistin resistance (50.9\%), followed by $A$. baumannii and $P$. aeruginosa with a resistance rate of $28.9 \% ; 21.4 \%$, respectively. Although colistin resistance rates are reported 'low' percentages among $A$. baumannii and $P$. aeruginosa isolates worldwide $e^{[20]}$, the high colistin resistance determined in our study among these groups was considered worrisome. The high proportion of carbapenem resistant (CR) strains among the study isolates may have caused high colistin resistance rates. Besides, a high ratio of colistin resistance among CR Enterobacterales strains has been reported all around the world ${ }^{[20]}$.

Numerous studies have been reported comparing the reference $\mathrm{BMD}$ with the available commercial methods. Categorical agreements of colistin AST were mostly within acceptable limits by Vitek 2 in many studies ${ }^{[6,21]}$. Other automated AST systems such as MicroScan and $\mathrm{BD}$ Phoenix also supplied reproducible and accurate categorical results for the testing of colistin in Enterobacterales ${ }^{[5,22]}$. The main problem in determining the sensitivity of colistin with automated systems is that the results obtained by these systems, with high very major errors (VMEs) rate, do not reliably distinguish colistin susceptible/resistant isolates.

In this study, the Vitek 2 showed rates of 92.4\% CA, among all 657 isolates. Furthermore, $14.5 \%$ of very major errors (VMEs), $1.7 \%$ of major errors (MEs) were observed. In the study by Tanriverdi et al. ${ }^{[22]}$ evaluating the performance of Vitek 2 according to $\mathrm{BMD}$, the rates of $\mathrm{CA}$, VMEs and MEs are as follows; 84.12\%, 55.88\% and $1.09 \%$. Chew et al. reported that for colistin testing CA was $<90 \%$ (67/76 isolates), with high VMEs rate $36 \%[16]$

Although Vitek 2 represented acceptable CA 
between referance BMD generally, significant differences of agreement were observed according to the bacterial species evaluated and resistant property of target isolates. Among Enterobacterales isolates, Vitek showed CA (100\%) rates for $E$. clocae complex and $E$. coli were higher than those obtained for $K$. pneumoniae (CA 93.3\%) (Table 3). While the highest very major error rate among Enterobacterales was detected in $K$. pneumoniae isolates (12.4\%); no false susceptible isolates were observed in $E$. coli and E. cloacae complex isolates. Vitek 2 showed poor performance for non-fermentative isolates, determined unacceptable $\mathrm{CA}$ rates for A. baumannii and $P$. aeruginosa $86.7 \%$; $85.7 \%$ respectively. While the highest VME rate (42.3\%) was found in $A$. baumanni; the highest $\mathrm{ME}$ (16.6\%) rate was observed in $P$. aeruginosa. High rates of MEs (16.6\%) reported for $P$. aeruginosa in that study could be due to the low number of isolates ( $n=14 / 2.1 \%$ ), which can magnify $\mathrm{ME}$ rates even with few false resistant results. Similar to our results, Vourli et al. have reported unacceptable EA and CA of $88.9 \%$ and $89.7 \%$ respectively, on a greater number of A. baumannii isolates $(\mathrm{n}=117)$, which contained 29 (24.8\%) colistin-resistant isolates. In addition, Vitek-2 showed unacceptable rates of VMEs $(37.9 \%)$ in this study ${ }^{[6]}$. The principal disadvantage of the Vitek 2 is its' poor performance to detect resistant subpopulations (heteroresistance) [23]. Heteroresistance can be expansively describe as the existence of subpopulations with an MIC higher (variably more than two-fold to eightfold) than the MIC of the basic population. This resistant subpopulation is clinically important as it may cause treatment failures ${ }^{[24]}$. Both of Acinetobacter spp. and Enterobacter spp. have been reported in the literature as wellknown producers of heteroresistant populations. Therefore, it could be a limiting factor on performance of automated systems such as Vitek $2^{[25]}$. On the account the fact that the number of E. cloacae complex isolates in this study is very low to be represented; resistant subpopulation, false susceptible or false resistant isolates may not have been detected at all.

In this study, Vitek 2 showed variable performance between different gram-negative bacteria species for colistin susceptibility testing, with a categorical concordance of $85.7 \%$ $-100 \%$. In one of the recent studies, it has been emphasized that the isolates with MICs of $\leq 0.5$ and $\geq 16 \mathrm{mg} / \mathrm{L}$ by Vitek 2 was perfectly compatible with broth microdilution ${ }^{[25]}$. In another study, it was stated that isolates determined by Vitek 2 MICs between 1 to 4 should be repeated with $\mathrm{BMD}$; the rest of the isolates having $\mathrm{MICs}$ of $<1 \mathrm{mg} / \mathrm{L}$ and $>4 \mathrm{mg} / \mathrm{L}$ can be released without any testing ${ }^{[26]}$. Vourli et al. have reported that VMEs were more frequent by both automated (Vitek 2 and Phoneix) isolates with MICs of $2 \mathrm{mg} / \mathrm{L}$ rather than $<1 \mathrm{mg} / \mathrm{L}$, refering that isolates $\mathrm{MIC}$ values close to the susceptibility breakpoint should be favourably retested by referance $\mathrm{BMD}^{[6]}$. In contrast, based on the results of our study, the majority of isolates (35/44, 79.5\%) determined VME were found $\mathrm{MIC} \leq 0.5 \mathrm{mg} / \mathrm{L}$ by Vitek 2 . In addition to that, ll of the $A$. baumannii isolates detected as false susceptible $(n=11)$ were found as $\mathrm{MIC}<=0.5$ mg/L by Vitek 2 .

In spite of high concordance (kappa value= 0.85) with BMD in this study, Vitek 2 was detected to be unreliable due to unacceptable high rates VMEs (14.5\%). Moreover, it cannot be recommended for colistin antibiotic susceptibility test (AST).

Polymyxins are cationic large molecules which hardly diffuse into agar. This property causes false sensitive test results in Etest. Among previous studies comparing gradient test with BMD for colistin AST, good categorical and essential agreement have been observed in some ${ }^{[16]}$, while some has shown low performance ${ }^{[21]}$. Several studies have shown that colistin susceptibility test results obtained by Etest methods have high very major error rates ${ }^{[15,16,21]}$, some of them as high as $41.5 \%[2]$. Etest result was correlated moderate agreement (kappa value $=0.45$ ) with inhouse reference tests in the present study. The results were poorer for Etests (CA: 63.6\%-80\% depending on bacterial species).

The lowest categorical agreement (63.6\%) and the highest VMEs rate (40\%) among isolates was observed in A. baumanni species by Etest. With the gradient tests, a larger number of resistant 
isolates were overlooked, resulting in a significant amount of false susceptible results (57 of total 203 isolates) in this study. A previous study has reported that colistin Etest demonstrated good performance, close to $90 \% \mathrm{CA}$, moreover, the very major error (VME) rate was found to be high $(12 \%$ to $36 \%)$, similar to our results ${ }^{[16]}$.

The strength of the present study is the included isolates, in particularly, colistin resistant $K$. pneumoniae isolates, are represented adequately in the study. The limiting factors of this study is that the Etest method was not applied to all isolates and colistin resistance genes could not be detected by molecular methods.

\section{CONCLUSION}

The importance of reliable colistin susceptibility test method has increased. However, colistin AST still remains a big challenge for many laboratories. Although we detected that the agreement of Vitek 2 with BMD was higher than the Etest-BMD in our study; the VME rates of both methods were determined to be above acceptable limits. Previous studies have reported that it may be useful in clinical settings to propose stringent MIC breakpoints considering heteroresistant isolates and mcr-1 carrying strains (which is MIC close to breakpoint) ${ }^{[16]}$. On the contrary, colistin resistant isolates will be underestimated by reducing susceptibility studies to a specific MIC since the MICs of VME isolates determined by Vitek 2 were mostly $<=$ $0.5 \mathrm{mg} / \mathrm{L}$ in our study.

Based on the results of this study, it may be recommended not to rely on Vitek 2 and colistin gradient test results. It may also cause treatment failure not to prefer performing the broth microdilution method due to the specific MIC value being above or below. Finally, our suggestion to laboratories is to improve their skills and necessary infrastructure to use the broth microdilution method in their routine workflow.

\section{ETHICS COMMITTEE APPROVAL}

This study was approved by the Necmettin Erbakan University Research Ethics Committee [protocol number: 2020/2914, permission date: November 20, 2020].

\section{CONFLICT of INTEREST}

No conflict of interest was declared by the authors.

\section{AUTHORSHIP CONTRIBUTIONS}

Concept and Design: SU, MD

Data Collection or Processing: SU

Analysis/Interpretation: $\mathrm{MD}, \mathrm{SU}$

Literature Search: SU

Writing: SU

Final Approval: MD, SU

\section{REFERENCES}

1. Doymaz MZ, Karaaslan E. Comparison of antibacterial activities of polymyxin $B$ and colistin against multidrug resistant Gram negative bacteria. Infect Dis 2019;5(9):676-82.

2. Dafopoulou K, Zarkotou O, Dimitroulia E, Hadjichristodoulou C, Gennimata V, Pournaras S, et al. Comparative evaluation of colistin susceptibility testing methods among carbapenem-nonsusceptible Klebsiella pneumoniae and Acinetobacter baumannii clinical isolates. Antimicrob Agents Chemother 2015;59(8):4625-30.

3. Rojas LI, Salim M, Cober E, Richter SS, Perez F, Salata RA, et al. Colistin resistance in carbapenem-resistant Klebsiella pneumoniae: laboratory detection and impact on mortality. Clin Infect Dis 2017;64(6):711-8.

4. Matar KM, Al-Refai B. Quantification of colistin in plasma by liquid chromatography-tandem mass spectrometry: application to a pharmacokinetic study. Sci Rep 2020;10(1):1-15.

5. Koyuncu Özyurt Ö, Özhak B, Ögünç D, Yildiz E, Çolak D, Günseren $F$, et al. Evaluation of the BD Phoenix 100 system and colistin broth disk elution method for antimicrobial susceptibility testing of colistin against gram-negative bacteria. Mikrobiyol Bul 2019;53(3):254-61.

6. Vourli S, Dafopoulou K, Vrioni G, Tsakris A, Pournaras S. Evaluation of two automated systems for colistin susceptibility testing of carbapenem-resistant Acinetobacter baumannii clinical isolates. Journal of Antimicrob Chemother 2017;72(9):2528-30.

7. Kulengowski B, Ribes JA, Burgess DS. Polymyxin B Etest $\AA$ compared with gold-standard broth microdilution in carbapenem-resistant Enterobacteriaceae exhibiting a wide range of polymyxin B MICs. Clin Microbiol Infect 2019;25(1):92-5.

8. Asar L, Pfefferle S, Lütgehetmann M, Hoffmann A, Katchanov J, Aepfelbacher $M$, et al. Influence of local epidemiology on the performance of common colistin drug susceptibility testing methods. Plos One 2019;14(6):e0217468.

9. EUCAST. Antimicrobial susceptibility testing of colistin-problems detected with several commercially available products. Available from: http://www.eucast.org/ast_of_bacteria/ warnings/ (Accessed date: 8 Aug 2017). 
10. The European Committee on Antimicrobial Susceptibility Testing. Breakpoint tables for interpretation of MICs and zone diameters, version10.0, 2020.

11. International Organization for Standardization (ISO). Clinical Laboratory Testing and In Vitro Diagnostic Test Systems. Susceptibility Testing of Infectious Agents and Evaluation of Performance of Antimicrobial Susceptibility Test Devices. Part 2: Evaluation of Performance of Antimicrobial Susceptibility Test Devices. International Standard 20776-2. Geneva, Switzerland: ISO, 2007.

12. The Clinical and Laboratory Standards Institute. Verification of commercial Microbial Identification and Antimicrobia Susceptibility Testing Systems. $1^{\text {st }}$ ed. CLSI Document M52Ed1. Wayne, PA: The Clinical and Laboratory Standards Institute; 2017.

13. Anantharajah A, Glupczynski $Y$, Hoebeke $M$, Bogaerts $P$, Declercq P, Denis $O$ et al. Multicenter study of automated systems for colistin susceptibility testing. Eur / Clin Microb Infect Dis 2020;1-5.

14. Nusrat T and Haque M. Mobile Colistin Resistance (MCR) Gene, antimicrobial resistance: a global public health threat. Bangladesh J Med Sci 2020;19(1):5-10.

15. Matuschek E, Åhman J, Webster C, Kahlmeter G. Antimicrobial susceptibility testing of colistin-evaluation of seven commercial MIC products against standard broth microdilution for Escherichia coli, Klebsiella pneumoniae, Pseudomonas aeruginosa, and Acinetobacter spp. Clin Microbiol Infect 2018;24(8):865-70.

16. Chew KL, La MV, Lin RT, Teo JW. Colistin and polymyxin B susceptibility testing for carbapenem-resistant and mcr-positive Enterobacteriaceae: comparison of Sensititre, MicroScan, Vitek 2, and Etest with broth microdilution. I Clin Microbiol 2017;55(9):2609-16.

17. Kocak CO, Hazirolan G. Colistin resistance in carbapenem-resistant Klebsiella pneumoniae clinical isolates. Turk Mikrobiyoloji Cem Derg 2019;49:17-23.

18. Yıldız SS, Kaşkatepe B, Şimşek H, Sarıgüzel FM. High rate of colistin and fosfomicin resistance among carbapenemase-producing Enterobacteriaceae in Turkey. Acta Microbiol immun Hungarica 2018;103-112.

19. Kansak N, Aslan M, Adaleti R, Aksaray S. Klebsiella pneumoniae izolatlarında sIVı mikrodilüsyon temelli iki ticari sistemin referans mikrodilüsyon yöntemine göre değerlendirilmesi. Mikrobiyol Bul 2020;54(4):606-12.
20. Santimaleeworagun $W$, Thunyaharn $S$, Juntanawiwat $P$, Thongnoy N, Harindhanavudhi S, Nakeesathit S, Teschumroon S. The prevalence of colistin-resistant Gram-negative bacteria isolated from hospitalized patients with bacteremia. J Appl Pharm Sci 2020;10:56-9.

21. Das S, Roy S, Roy S, Goelv G, Sinha S, Mathur P, et al. Colistin susceptibility testing of gram-negative bacilli: Better performance of Vitek2 system than E-test compared to broth microdilution method as the gold standard test. Indian I Med Microbiol 2020;38(1):58.

22. Tanrıverdi $Y$, Çınar C, Bilgin K, Vural DG, Birinci A. Kolistin direncinin saptanmasında SIVI mikrodilüsyon ve otomatize sistem sonuçlarının karşılaştırılması. Düzce Üniversitesi Sağlık Bilimleri Enstitüsü Dergisi 2020;10(3):297-301.

23. Lo-Ten-Foe JR, de Smet AMG, Diederen BM, Kluytmans JA, Van Keulen PH. Comparative evaluation of the VITEK 2, disk diffusion, Etest, broth microdilution, and agar dilution susceptibility testing methods for colistin in clinical isolates, including heteroresistant Enterobacter cloacae and Acinetobacter baumannii strains. Antimicrobial Agents Chemother 2007; 51(10):3726-3730.

24. Karakonstantis S, Saridakis I. Colistin heteroresistance in Acinetobacter spp; systematic review and meta-analysis of the prevalence and discussion of the mechanisms and potential therapeutic implications. Int / Antimicrobial Agents 2020;106065

25. Girardello R, Cury AP, Franco MR, Di Gióia TR, de Almeida $J N$ Jr, de Araújo MR et al. Colistin susceptibility testing and Vitek-2TM: Is it really useless? Diagn Microbiol Infect Dis 2018;91(4):309-311.

26. Wattal C, Goel N, Oberoi JK, Datta S and Raveendran R. Performance of three commercial assays for colistin susceptibility in clinical isolates and Mcr-1 carrying reference strain. Indian J Med Microbiol 2019;37(4):488.

\section{Address for Correspondence/Yazıșma Adresi}

\section{Dr. Selin UĞRAKLI}

Konya Halk Sağlığı Laboratuvarı,

Tıbbi Mikrobiyoloji Birimi

Konya-Türkiye

E-posta: dr.selinyumakci@gmail.com 